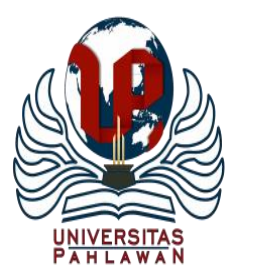

Jurnal Abdidas Volume 2 Nomor 3 Tahun 2021 Halaman 521-529

JURNAL ABDIDAS

http://abdidas.org/index.php/abdidas

\title{
Sosialisasi dan Penguatan Edukasi pada Siswa Terkait Penerapan Protokol Kesehatan di SDN 1 Masiri, demi Terciptanya Situasi Kondusif di Era New Normal
}

\author{
Hijrawatil Aswat ${ }^{1 凶}$, Eka Rosmitha Sari ${ }^{2}$, Mitrakasih La Ode Onde ${ }^{3}$, Alaudin ${ }^{4}$, Kiki Fatmala $^{5}$ \\ Pendidikan Guru Sekolah Dasar, Universitas Muhammadiyah Buton, Indonesia ${ }^{1,2,3,4,5}$ \\ E-mail: hijrawati171208@gmail.com ${ }^{1}$, ekarosmithasari@gmail.com² ${ }^{2}$ Mitralaodeonde@gmail.com ${ }^{3}$, \\ alaudin@gmail.com ${ }^{4}, \underline{\text { kikifatmala@gmail.com }}{ }^{5}$
}

\begin{abstract}
Abstrak
Untuk mempersiapkan dan mematangkan pemahaman siswa menghadapi new normal, perlu dilakukan edukasi dan eksekusi secara serius terkait penerapan protokol kesehatan, sehingga tidak hanya sekedar narasi berupa perintah penerapannya, namun memberikan pemahaman secara mendalam dan praktik kepada siswa sebagai bentuk kepedulian dan kesadaran diri dalam siswa setelah ia memahami maksud dan tujuan dari penerapan protokol kesehatan itu sendiri. Sasaran dalam kegiatan ini adalah siswa dan guru di SD Negeri 1 Masiri. Metode pelaksanaan kegiatan terdiri dari 3 tahap kegiatan, di antaranya 1) kegiatan sosialisasi yang dilakukan melalui metode ceramah terkait panduan pelaksanaan pembelajaran tatap muka bagi daerah zona hijau dimasa pandemik melalui penerapan protokol kesehatan; 2) kegiatan simulasi, dengan mempraktikkan secara langsung tahapan pelaksanaan protokol kesehatan secara runtut dan tepat; 3) kegiatan evaluasi, pembagian masker gratis, hand sanitizer, dan sabun cuci tangan. Kegiatan ini dianggap penting, merujuk pada beberapa pengabdian serupa yang belum menekankan pada pembentukan kesadaran dalam diri anak dan menanamkan kebiasaan baru secara runtut terkait protokol kesehatan. Hasil Pengabdian kepada masyarakat menunjukkan hasil yang cukup memuaskan, berdasarkan analisis perbandingan sebelum dan setelah kegiatan dilaksanakan menunjukkan adanya perubahan perilaku ke arah positif.
\end{abstract}

Kata kunci: edukasi siswa, protokol kesehatan, new normal

\section{Abstract}

To prepare and finalize students' understanding of facing the New Normal, it is necessary to carry out serious education and execution related to the application of health protocols, so that it is not just a narrative in the form of instructions for its application but provides in-depth understanding and practice to students as a form of concern and self-awareness in students after they understand the aims and objectives of implementing the health protocol itself. The targets in this activity are students and teachers at SD Negeri 1 Masiri. The method of implementing the activity consists of 3 stages of activities, including 1) socialization activities carried out through the lecture method related to face-to-face learning implementation guidelines for green zone areas during the pandemic period through the application of the Health protocol; 2) simulation activities, by directly practicing the stages of implementing the Health protocol in a coherent and precise manner; 3) Evaluation activities, distributing free masks, hand sanitizers, and hand washing soap. This activity is considered important, referring to several similar services that have not emphasized the formation of awareness in children and inculcating new habits coherently related to health protocols, The results of community service showed satisfactory results, based on the comparative analysis before and after the activity was carried out, it showed that there was a change in behavior in a positive.

Keywords: student education, health protocols, new normal

Copyright (c) 2021 Hijrawatil Aswat, Eka Rosmitha Sari, Mitrakasih La Ode Onde, Alaudin, Kiki Fatmala

$\triangle$ Corresponding author

Address : Betoambari No.36 Kota Baubau

Email : hijrawati aswat@yahoo.co.id

DOI $\quad:$ https://doi.org/10.31004/abdidas.v2i3.310

ISSN 2721- 9224 (Media Cetak)

ISSN 2721- 9216 (Media Online) 
522 Sosialisasi dan Penguatan Edukasi pada Siswa Terkait Penerapan Protokol Kesehatan di SDN 1 Masiri, demi Terciptanya Situasi Kondusif di Era New Normal- Hijrawatil Aswat, Eka Rosmitha Sari, Mitrakasih La Ode Onde, Alaudin, Kiki Fatmala

DOI: https://doi.org/10.31004/abdidas.v2i3.310

\section{PENDAHULUAN}

Negara Indonesia saat ini masuk daftar penyebaran virus Covid-19 yang dimulai sejak awal Maret 2020. Kasus konfirmasi Covid terus bertambah dan menghentikan laju segala sektor, baik dari segi perekonomian, pendidikan, pariwisata, dan lain sebagainya. Lonjakan pasien positif Covid terus terjadi dan kian meningkat, sehingga perlu adanya peran dan kiat terkait upaya penanggulangan dan memutus rantai penyebaran yang lebih meluas. Peran penting masyarakat dalam ikut memutus rantai penyebaran Covid-19 dengan mengikuti segala anjuran pemerintah. Menindaklanjuti instruksi presiden, Nomor 6 Tahun 2020 tentang peningkatan disiplin dan penegakan hukum protokol kesehatan dalam pencegahan dan pengendalian Covid-19, dimana upaya ini terus dilakukan dan sebagai bentuk kesungguhan untuk pencegahannya dan ditekankan pula tentang sanksi dan penegakan hukum bagi pelanggar yang tertuang dalam inpres No.6/2020,(Kabinet et al., 2019). Sehingga masyarakat wajib mematuhi segala peraturan protokol kesehatan sebagai bentuk dukungan dalam menghentikan laju penyebaran yang lebih meluas.

Kementrian Pendidikan dan Kebudayaan telah menghimbau pelaksanaan pendidikan di masa pandemi Covid-19 lebih mengutamakan kesehatan dan keselamatan peserta didik dan tenaga kependidikan, sehingga segala aktivitas belajar dilakukan dari rumah masing-masing dengan memanfaatkan sistem teknologi (daring). Alternatif ini dianggap paling efektif untuk membatasi interaksi sosial secara langsung, namun tetap memenuhi layanan pendidikan (Anugrahana, 2020).

Tahun 2021 saat ini, dikenal dengan masa new normal (Sahputri \& Sofia, 2020). New normal adalah perubahan perilaku untuk tetap menjalankan aktivitas normal dengan ditambah menerapkan protokol kesehatan, guna mencegah terjadinya penularan Covid-19. Masa ini menuntut semua orang untuk melakukan adaptasi terhadap kondisi lingkungan yang masih dalam situasi pandemi, dengan diperbolehkannya melakukan aktivitas normal, namun tetap dalam situasi penegakan protokol kesehatan. Termasuk di sekolah, protokol kesehatan merupakan aturan utama untuk melindungi siswa dari paparan penyebaran Covid selama pembelajaran tata muka dilaksanakan dengan tetap memperhatikan kesehatan dan keselamatan warga sekolah. Sesuai SKB Menteri Pendidikan dan Kebudayaan tentang panduan penyelenggaraan pembelajaran pada tahun ajaran 2020/2021 di masa pandemi corona virus Diases 2019 (Kementrian Kesehatan Republik Indonesia, 2020) bahwa pembelajaran tatap muka dapat dilakukan di wilayah zona hijau dengan ketentuan setelah memenuhi semua daftar periksa dan terasa siap, serta adanya persetujuan dari pemerintah daerah dan orang tua siswa. Satuan pendidikan yang berada pada zona hijau dan siap melaksanakan pembelajaran secara tatap muka, harus mematuhi dan menerapkan protokol kesehatan di antaranya memakai masker, mencuci tangan, dan menjaga jarak, selama berada di lingkungan sekolah. 
523 Sosialisasi dan Penguatan Edukasi pada Siswa Terkait Penerapan Protokol Kesehatan di SDN 1 Masiri, demi Terciptanya Situasi Kondusif di Era New Normal- Hijrawatil Aswat, Eka Rosmitha Sari, Mitrakasih La Ode Onde, Alaudin, Kiki Fatmala

DOI: https://doi.org/10.31004/abdidas.v2i3.310

Siswa di sekolah dasar perlu mendapat perhatian dan kehati-hatian dalam pelaksanaan new normal, mengingat rentan usia yang masih dalam kategori kanak-kanak, dimana sistem imunitas tubuh belum kuat dibandingkan orang dewasa, dan juga masih membutuhkan bimbingan secara langsung dari guru, diberikan pemahaman dan pembiasaan terkait penerapan protokol kesehatan. Kasus Covid-19 pada anak yang dirilis IDAI hingga 18 Mei 2020 (Manonjaya \& Tasikmalaya, 2021) kasus Covid-19 pada anakanak sebanyak 3.324 kasus, 129 anak berstatus PDP meninggal dunia, 584 kasus anak terkonfirmasi positif Covid-19, dan 14 anak meninggal akibat Covid-19. Tentu hal ini menjadi Bahan pertimbangan dan pembelajaran bagi sekolah khususnya di sekolah dasar agar lebih mengutamakan kesehatan anak-anak. Segala aktivitas anak harus terpantau karena diusia mereka, anak lebih banyak menghabiskan aktivitasnya dalam kegiatan bermain dan interaksi sosial. termasuk di SDN 1 Masiri adalah salah satu sekolah yang masuk kategori zona hijau, sehingga dapat melaksanakan pembelajaran tatap muka secara sistem shift. Untuk mempersiapkan dan mematangkan pemahaman siswa menghadapi new normal, perlu dilakukan edukasi dan eksekusi secara serius terkait penerapan protokol kesehatan, sehingga tidak hanya sekedar narasi berupa perintah penerapannya, namun memberikan pemahaman secara mendalam dan praktik kepada siswa sebagai bentuk kepedulian dan kesadaran diri dalam siswa setelah ia memahami maksud dan tujuan dari penerapan protokol kesehatan itu sendiri. Menurut Notoatmojo, 2010 (Syah et al., 2020) Perilaku seseorang dapat dipengaruhi oleh faktor-faktor seperti pengetahuan, sikap, motivasi, dan lingkungan. Sehingga melalui kegiatan ini dapat merubah perilaku siswa dalam membentuk kebiasaan baru dengan benar, terkait penerapan protokol kesehatan. Pengabdian yang telah dilakukan oleh (Anita et al., 2020) terkait penerapan protokol kesehatan, dengan memberikan pemahaman kepada orang tua siswa dalam mendampingi anak menerapkan protokol kesehatan serta pendampingan pembuatan alat atau wadah mencuci tangan, begitupun pada pengabdian yang telah dilakukan oleh (Wijanarko et al., 2021) terkait optimalisasi penerapan protokol kesehatan penanganan Covid-19 pada fase new normal melalui literasi media, dengan membuat papan media dalam mensosialisasikan penerapan protokol kesehatan. Sehingga tim PKM bermaksud untuk mensosialisasikan dan memberikan penguatan edukasi penerapan protokol kesehatan kepada siswa melalui metode simulasi atau praktik langsung ke siswa, dan membentuk pembiasaan baru secara sistematis atau sesuai dengan langkah penerapan mulai dari rumah, memasuki lingkungan sekolah, dan keluar dari lingkungan sekolah. Hal demikian dapat menjadi pembiasaan bagi siswa dan lebih teratur atau tersistem.

\section{METODE}

Sasaran dalam kegiatan ini adalah siswa dan guru di SDN 1 Masiri. Waktu pelaksanaan kegiatan dimulai dari tanggal 11-14 Januari 2021 yang 
524 Sosialisasi dan Penguatan Edukasi pada Siswa Terkait Penerapan Protokol Kesehatan di SDN 1 Masiri, demi Terciptanya Situasi Kondusif di Era New Normal- Hijrawatil Aswat, Eka Rosmitha Sari, Mitrakasih La Ode Onde, Alaudin, Kiki Fatmala

DOI: https://doi.org/10.31004/abdidas.v2i3.310

bertempat di SDN 1 Masiri. Metode pelaksanaan kegiatan melalui 3 tahapan, yakni: 1) metode ceramah, digunakan dalam mensosialisasikan peraturan pemerintah terkait panduan pelaksanaan pendidikan dan penerapan protokol kesehatan dimasa new normal, di antaranya tata cara penyelenggaraan pembelajaran di masa pandemi, langkah penerapan protokol kesehatan seperti cara mencuci tangan yang benar, cara memakai dan melepas masker, aturan maksimal lamanya penggunaan masker, pembatasan interaksi sosial, serta etika batuk dan bersin; 2) metode simulasi protokol kesehatan, sebagai bentuk penguatan edukasi dalam penerapan protokol kesehatan dengan mempraktikkan atau mensimulasikan secara langsung kepada siswa terkait cara cuci tangan sesuai dengan langkah-langkah dari panduan WHO, mensimulasikan cara memakai dan melepas masker, cara membersihkan masker, cara komunikasi tanpa interaksi, serta etika batuk dan bersin. 3) Evaluasi dan pembagian masker, sabun cuci tangan serta hand sanitizer.

\section{HASIL DAN PEMBAHASAN}

Menghadapi new normal saat ini, dalam penerapan adaptasi pembiasaan baru, siswa harus dilibatkan dalam membangun kesadaran dalam diri terkait penerapan protokol kesehatan, agar terbentuk kebiasaan baru dalam aktivitasnya yang didasari atas kemauan dan kesadaran masingmasing individu. Siswa sekolah dasar patut dilakukan pantauan secara ketat, mengingat aktivitas kanak-kanak banian dihabiskan dalam interaksi sosial, sehingga untuk mencegah penyebaran secara masif, pondasi utama yang perlu dikokohkan ada pada diri siswa itu sendiri. Sehingga diperlukan adanya penguatan edukasi menyambut new normal terkait penerapan protokol kesehatan di lingkungan sekolah. Kegiatan ini diawali dengan pemetaan wilayah dan sekolah yang masuk zona hijau dan melaksanakan kegiatan pembelajaran di sekolah. Mengingat zona hijau merupakan zona resiko rendah, namun tetap patut diwaspadai.

Sosialisasi dilaksanakan di SDN 1 Masiri setelah melakukan kesepakatan dengan pihak sekolah terkait waktu pelaksanaan yang tepat tanpa mengganggu aktivitas belajar siswa dan tetap menerapkan protokol kesehatan. Sehingga pelaksanaan sosialisasi dilaksanakan oleh masingmasing tim pada masing-masing kelas, guna menghindari penumpukan siswa pada satu ruangan. Kegiatan sosialisasi dihadiri oleh siswa dan masing-masing guru kelas dengan sistem penjadwalan secara bertahap atau shift. Kegiatan ini berlangsung selama 2 hari dengan durasi waktu masing-masing $30 \mathrm{menit} /$ shift. Setiap anggota pelaksana kegiatan PKM bertanggungjawab mensosialisasikan penyelenggaraan pembelajaran di kelas berdasarkan buku panduan pembelajaran pada tahun ajaran 2020/2021 (Kemdikbud, 2020), dengan ketentuan selama masa transisi, sekolah perlu memperhatikan tatap muka dengan jumlah hari dalam seminggu, jumlah jam dalam sehari, dan jumlah rombongan/shift. Selanjutnya memasuki masa new normal yang dapat melaksanakan kegiatan pembelajaran seperti sedia kala dengan tetap memperhatikan kondisi kesehatan dan 
525 Sosialisasi dan Penguatan Edukasi pada Siswa Terkait Penerapan Protokol Kesehatan di SDN 1 Masiri, demi Terciptanya Situasi Kondusif di Era New Normal- Hijrawatil Aswat, Eka Rosmitha Sari, Mitrakasih La Ode Onde, Alaudin, Kiki Fatmala

DOI: https://doi.org/10.31004/abdidas.v2i3.310

keselamatan warga sekolah serta mematuhi protokol kesehatan dan wajib menutup kembali pembelajaran tatap muka di satuan pendidikan zona hijau apabila terindikasi tidak aman atau tingkat resiko daerahnya berubah. Sehingga dalam sosialisasi ini, disampaikan pula tata cara penerapan protokol kesehatan yang benar dan manfaatnya, diantanya tata cara mencuci tangan yang tepat melalui air yang mengalir dan menggunakan cairan pembersih tangan (hand sanitizer), cara memakai dan melepas masker tanpa menyentuh bagian depan masker, aturan pemakaian masker kain 3 lapis atau 2 lapis yang diisi tisu serta mengganti masker setelah penggunaan selama 4 jam, pembatasan interaksi sosial melalui jaga jarak minimal 1,5 meter dengan ketentuan tidak melakukan kontak fisik dan tidak menyentuh area wajah/muka setelah menyentuh benda di sekitar kelas, menerapkan etika batuk dan bersin dengan menutup area mulut menggunakan tisu atau lengan atas bagian dalam tanpa menyentuh area wajah lainnya dan membuang tisu bekas pakai serta membersihkan benda yang tercemar percikan bersin.

Simulasi protokol kesehatan dilaksanakan pada hari ketiga, sebagai bentuk penguatan edukasi kepada siswa terkait penerapan protokol kesehatan secara tepat. Kegiatan ini dilaksanakan sebelum siswa memasuki ruang belajarnya atau kelas. Setelah siswa melakukan pengecekan suhu tubuh sebelum memasuki lingkungan sekolah, siswa dipastikan telah memakai masker dengan benar, selanjutnya setiap siswa mencuci tangan pada wadah yang telah disediakan yang didampingi oleh tim pelaksana PKM dengan menyediakan sabun pencuci tangan dan hand sanitizer, guna memastikan siswa telah melakukan langkah mencuci tangan yang tepat sesuai dengan anjuran WHO.

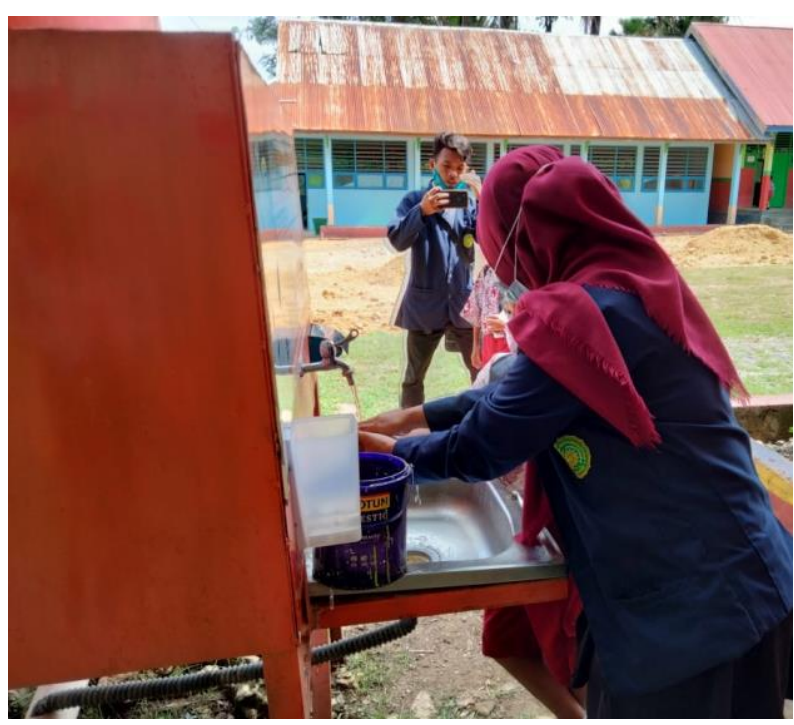

Gambar 1. Praktik Cara Mencuci Tangan yang Benar

Kegiatan ini sebagai bentuk edukasi kepada siswa agar membentuk kebiasaan baru dalam menjaga kebersihan tangan, sehingga meskipun tanpa perintah dan bimbingan guru, siswa telah dapat melakukan protokol kesehatan secara mandiri, serta menanamkan kesadaran dalam diri siswa akan pentingnya melindungi diri dari bahaya penyebaran virus. Setelah siswa mempraktikkan cara mencuci tangan yang benar, selanjutnya siswa diarahkan memasuki ruang kelasnya dan mensimulasikan cara memakai dan melepas masker yang benar tanpa menyentuh area muka atau wajah dan tanpa menyentuh permukaan masker. 
526 Sosialisasi dan Penguatan Edukasi pada Siswa Terkait Penerapan Protokol Kesehatan di SDN 1 Masiri, demi Terciptanya Situasi Kondusif di Era New Normal- Hijrawatil Aswat, Eka Rosmitha Sari, Mitrakasih La Ode Onde, Alaudin, Kiki Fatmala

DOI: https://doi.org/10.31004/abdidas.v2i3.310

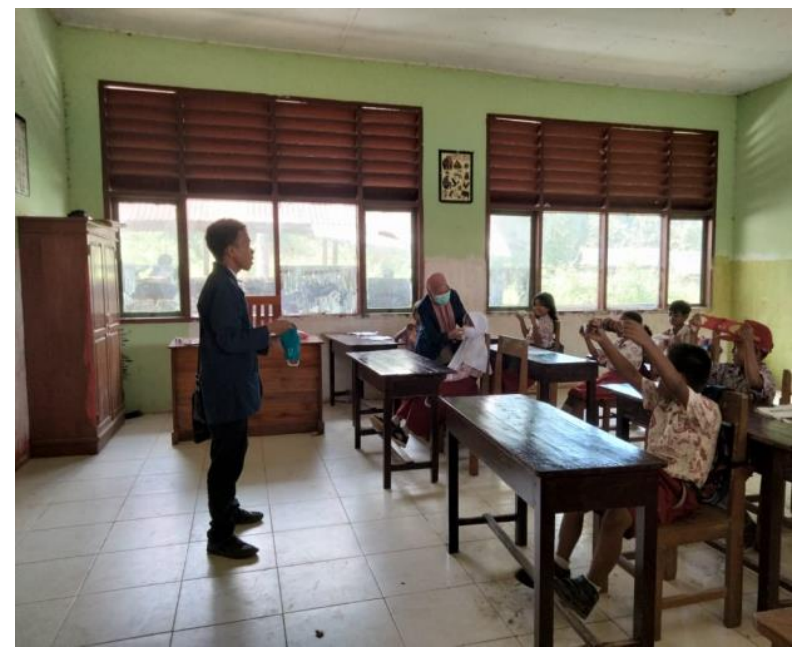

Gambar 2. Cara Memakai dan Melepas Masker yang Tepat

Siswa diedukasi pula bagaimana cara perawatan masker kain yang dapat digunakan kembali setelah dicuci, dan cara melepas masker dan membuangnya ke tempat sampah bagi masker sekali pakai. Selanjutnya siswa diberikan contoh interaksi sosial yang benar dengan menjaga jarak tanpa interaksi fisik dan tanpa menyentuh area muka atau wajah setelah menyentuh benda di sekitar kelas.

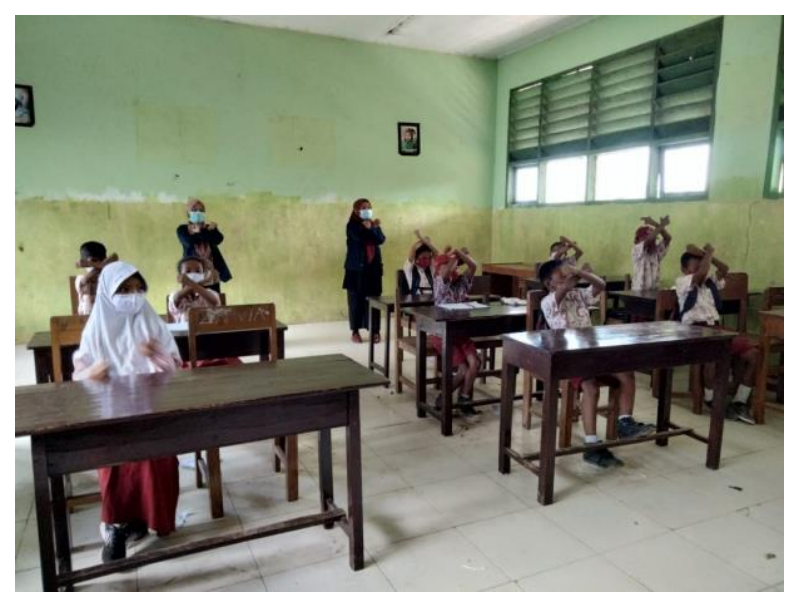

Gambar 3. Pola Interaksi Tanpa Sentuhan Fisik
Dipastikan siswa hanya melakukan aktivitas belajar selama berada di kelas dan setelah keluar dari ruang kelas, siswa diarahkan kembali untuk mencuci tangan sebelum kembali ke rumah masing-masing. Dalam kegiatan simulasi ini pula, siswa diedukasi bagaimana etika batuk dan bersin. Tim Pelaksana PKM memberikan contoh cara batuk dan bersin yang salah, selanjutnya memberikan contoh cara batuk dan bersin yang tepat, kegiatan ini disimulasikan kembali oleh siswa untuk memastikan siswa telah melakukannya dengan tepat.

Evaluasi dilaksanakan setelah kegiatan sosialisasi dan simulasi dilaksanakan. Tujuannya untuk melakukan pengamatan secara langsung kepada siswa dalam menerapkan protokol kesehatan dengan benar dan secara runtut secara mandiri. Selanjutnya sebagai ucapan terimakasih dan motivasi kepada siswa dalam melaksanakan protokol kesehatan, tim pelaksana PKM membagikan masker gratis kepada siswa, menyediakan sabun cuci tangan, dan hand sanitizer yang dapat digunakan ketika berada di ruang kelas. 
527 Sosialisasi dan Penguatan Edukasi pada Siswa Terkait Penerapan Protokol Kesehatan di SDN 1 Masiri, demi Terciptanya Situasi Kondusif di Era New Normal- Hijrawatil Aswat, Eka Rosmitha Sari, Mitrakasih La Ode Onde, Alaudin, Kiki Fatmala

DOI: https://doi.org/10.31004/abdidas.v2i3.310

Tabel 1. Perbandingan Sebelum dan Setelah Pelaksanaan Kegiatan

\begin{tabular}{|c|c|c|c|}
\hline No & Kondisi Awal & Pelaksanaan & Uji Coba \\
\hline 1. & $\begin{array}{l}\text { Belum menerapkan } \\
\text { secara runtut pelaksanaan } \\
\text { protokol kesehatan }\end{array}$ & $\begin{array}{l}\text { Diberi edukasi tentang langkah } \\
\text { penerapan protokol kesehatan } \\
\text { mulai dari memasuki gerbang } \\
\text { sekolah, memasuki ruang kelas, } \\
\text { hingga keluar dari lingkungan } \\
\text { sekolah. }\end{array}$ & $\begin{array}{l}\text { Memahami Langkah penerapan protokol } \\
\text { kesehatan, ditandai dengan kemampuan siswa } \\
\text { melaksanakan tahapan protokol kesehatan, } \\
\text { mulai dari penggunaan masker, pengecekan } \\
\text { suhu tubuh, mencuci tangan sebelum memasuki } \\
\text { ruang kelas, memasuki ruang kelas dengan } \\
\text { menjaga jarak, mencuci tangan dan memakai } \\
\text { hand sanitizer setelah meninggalkan ruang kelas } \\
\text { dan kembali ke rumah masing-masing siswa. }\end{array}$ \\
\hline 2. & $\begin{array}{l}\text { Belum memiliki } \\
\text { keterampilan menerapkan } \\
\text { protokol kesehatan }\end{array}$ & $\begin{array}{l}\text { Dilatih cara penerapan protokol } \\
\text { kesehatan yang tepat }\end{array}$ & $\begin{array}{l}\text { Memiliki keterampilan dalam menerapkan } \\
\text { protokol kesehatan secara mandiri, mulai dari } \\
\text { kemampuan mencuci tangan yang tepat, } \\
\text { kemampuan memakai dan melepas masker yang } \\
\text { tepat, kemampuan menjaga kebersihan masker } \\
\text { dan layak pakai, kemampuan melakukan cara } \\
\text { batuk dan bersin yang tepat. }\end{array}$ \\
\hline 3. & $\begin{array}{l}\text { Belum memiliki } \\
\text { kesadaran dalam diri } \\
\text { siswa dalam menerapkan } \\
\text { protokol kesehatan }\end{array}$ & $\begin{array}{l}\text { Diberikan pemahaman dengan } \\
\text { memaparkan tujuan dari } \\
\text { penerapan protokol kesehatan } \\
\text { dan bahaya jangkitan virus. }\end{array}$ & $\begin{array}{l}\text { Memiliki pemahaman dan menambah } \\
\text { pengetahuan serta pengalaman dalam } \\
\text { menjalankan protokol kesehatan secara mandiri, } \\
\text { tanpa perintah atau bimbingan guru, namun } \\
\text { siswa telah mampu membentuk kebiasaan baru } \\
\text { dan menjadi kebutuhan siswa setiap harinya } \\
\text { dalam menjalankan aktivitas belajar di sekolah. }\end{array}$ \\
\hline
\end{tabular}

Paparan tersebut menegaskan bahwa pelaksanakan kegiatan sosialisasi dan penguatan edukasi terkait penerapan protokol kesehatan di lingkungan sekolah sangatlah bermanfaat dan memiliki pengalaman tersendiri oleh peserta dan lebih menambah kesadaran diri siswa dalam menerapkan protokol kesehatan guna menjaga diri dan orang-orang di sekitar dari penyebaran virus berbahaya.

\section{SIMPULAN}

Program sosialisasi dan penguatan edukasi penerapan protokol kesehatan sebagai bentuk upaya menciptakan situasi kondusif di era new normal, guna mengantisipasi indikasi tingkat resiko yang tidak aman pada zona hijau. Sehingga kegiatan pembelajaran dapat dilaksanakan secara tatap muka dengan membentuk kebiasaan baru melalui penerapan protokol kesehatan dengan tepat dan sistematis, mulai dari (1) penggunaan masker dan cara melepaskan masker yang tepat; (2) pengecekan suhu tubuh sebelum memasuki lingkungan sekolah; (3) mencuci tangan dengan benar sebelum memasuki ruang kelas; (4) menjaga jarak dan tidak ada kontak fisik selama berada di lingkungan sekolah, terutama saat berada di dalam kelas; (5) tidak menyentuh area muka atau wajah setelah menyentuh benda di sekitarnya dan menggunakan hand sanitizer; (6) mencuci tangan setelah meninggalkan ruang kelas dan kembali ke rumah masing-masing. (7) melepas dan mencuci masker saat tiba di rumah menggunakan air mengalir dan detergen, bagi masker sekali pakai, dapat dilepaskan dan dibuang pada tempat 
528 Sosialisasi dan Penguatan Edukasi pada Siswa Terkait Penerapan Protokol Kesehatan di SDN 1 Masiri, demi Terciptanya Situasi Kondusif di Era New Normal- Hijrawatil Aswat, Eka Rosmitha Sari, Mitrakasih La Ode Onde, Alaudin, Kiki Fatmala

DOI: https://doi.org/10.31004/abdidas.v2i3.310

sampah, dan memastikan tangan kembali dicuci dengan benar. Kegiatan ini dilaksanakan secara bertahap mulai dari kegiatan sosialisasi melalui metode ceramah, selanjutnya kegiatan simulasi melalui praktik langsung oleh siswa, dan kegiatan evaluasi sekaligus pembagian masker gratis kepada siswa, sabun cuci tangan, dan hand sanitizer yang dapat digunakan ketika berada di dalam kelas. Berdasarkan evaluasi yang telah dilakukan dapat diajukan beberapa saran sebagai berikut: 1) bagi sekolah baiknya menyediakan peralatan protokol kesehatan yang lebih memadai, seperti penyediaan alat cuci tangan portable sehingga siswa tidak menyentuh keran setelah mencuci bersih tangannya, serta melakukan penyemprotan disinfektan secara teratur pada permukaan benda di sekitar sekolah; 2) bagi guru, mengkomunikasikan kepada orang tua siswa terkait disiplin protokol kesehatan yang diterapkan di sekolah, agar konsisten diterapkan pula saat berada di lingkungan rumah, serta terus mempromosikan pembatasan sosial dengan tidak melakukan pertemuan-pertemuan yang mengundang kerumunan atau jumlah orang yang banyak.

\section{UCAPAN TERIMA KASIH}

Kegiatan ini dapat terselesaikan dengan lancar dan sesuai target, tentu tak lepas dari dukungan berbagai pihak, terutama kekompakan tim dalam menjalankan tugas masing-masing dan dukungan dari pihak Sekolah Dasar Negeri 1 Masiri, serta dukungan dari Universitas Muhammadiyah Buton yang telah memberikan izin dan memberi support Kegiatan tersebut. Ucapan terima kasih kapada tim mahasiswa yang telah ikut serta berpartisipasi dalam kelancaran pelaksanaan kegiatan sekaligus menambah wawasan dan pengalaman di lapangan.

\section{DAFTAR PUSTAKA}

Anita, I., Hermawan, L., Junaedi, D., Buana, U. L., \& Buana, U. L. (2020). PENERAPAN PROTOKOL KESEHATAN DALAM UPAYA SEKOLAH BEBAS COVID-19. 2(2).

Anugrahana, A. (2020). Hambatan, Solusi dan Harapan: Pembelajaran Daring Selama Masa Pandemi Covid-19 Oleh Guru Sekolah Dasar. Scholaria: Jurnal Pendidikan Dan Kebudayaan, 10(3), 282-289. https://doi.org/10.24246/j.js.2020.v10.i3.p28 2-289

Kabinet, M., Maju, I., \& Nasional, T. (2019). Dalam rangka menjamin. 2019(031242).

Kemdikbud. (2020). Panduan Penyelenggaraan Pembelajaran di Masa Pandemi COVID-19. Kemendikbud, 2019, 1-58. https://www.kemdikbud.go.id/main/blog/202 0/06/buku-saku-panduan-pembelajaran-dimasa-pandemi-covid19

Kementrian Kesehatan Republik Indonesia. (2020). Pengawasan dan pembina an penerapan protokol kesehatan di satuan pendidikan.

Manonjaya, K. E. C., \& Tasikmalaya, K. A. B. (2021). $1 ; 2 ; 3 ; 4$. 2(1), 56-62.

Sahputri, J., \& Sofia, R. (2020). Penyuluhan Protokol Kesehatan Era Pandemi Coronavirus Disease (Covid-19) di SDN 14 Muara Dua Kota Lhokseumawe. Lentera: (Jurnal Ilmiah Sains, Teknologi, Ekonomi, Sosial Dan Budaya), 4(4), 53-57. http://journal.umuslim.ac.id/index.php/ltr2/ar ticle/view/135

Syah, D. Z. R., Utari, D., \& ... (2020). Edukasi Penerapan Protokol Kesehatan Penyelenggaraan Kegiatan Pada Masa Pandemi Covid 19 Di Tpq Masjid 
529 Sosialisasi dan Penguatan Edukasi pada Siswa Terkait Penerapan Protokol Kesehatan di SDN 1 Masiri, demi Terciptanya Situasi Kondusif di Era New Normal- Hijrawatil Aswat, Eka Rosmitha Sari, Mitrakasih La Ode Onde, Alaudin, Kiki Fatmala

DOI: https://doi.org/10.31004/abdidas.v2i3.310

Awalulmu'Minin .... Jurnal Pengabdian ...,

$2(2)$,

$28-33$.

http://jurnal.poltekkeskhjogja.ac.id/index.php /jpmkh/article/view/408

Wijanarko, A., Setiawan, Y., Efendi, R., Supratman, J. W., Limun, K., \& Bengkulu, K. (2021). Optimalisasi Pelaksanaan Penerapan Protokol Kesehatan Penanganan Covid-19 Pada Fase New Normal Melalui Literasi Media Di Sdit Iqra 1 Bengkulu. Abdi Reksa, 2(1), 51-58. www.ejournal.unib.ac.id/index.php/abdireksa 